\title{
RESEARCH PAPER \\ Fatty acid profile, quality lipid index and bioactive compounds of flour from grape residues
}

\author{
Leilane D. Lopes ${ }^{1}$, Bruna R. Böger ${ }^{1}$, Kelen F. Cavalli ${ }^{1}$ José F. dos S. \\ Silveira-Júnior ${ }^{1}$, Daniel V. C. L. Osório ${ }^{1}$, Débora F. de Oliveira², Luciano \\ Luchetta $^{1}$, and Ivane B. Tonial ${ }^{1}$ \\ 'Departamento de Tecnologia de Alimentos, Universidade Tecnológica Federal do Paraná/UTFPR, Linha \\ Santa Bárbara s/n, 85601-970, Francisco Beltrão, PR, Brazil. \\ ${ }^{2}$ Departamento de Engenharia de Alimentos, Universidade Federal de Rondônia/UNIR, Avenida Tancredo \\ Neves 3450, Setor Institucional, 76872-862, Ariquemes, RO, Brazil.
}

\begin{abstract}
L.D. Lopes, B.R. Böger, K.F. Cavalli, J.F. dos S. Silveira-Júnior, D.V.C.L. Osório, D.F, de Oliveira, L. Luchetta, and I.B. Tonial. 2014. Fatty acid profile, quality lipid index and bioactive compounds of flour from grape residues. Cien. Inv. Agr. 41(2): 225-234. The present study evaluated the proximate composition, the nutrition indexes of lipids and the presence of biologically active compounds in the flour of bagasse from grapes cultivated by conventional (CC) and organic (OC) methods. CC flour had high percentages of proteins, lipids, calories and saturated and monounsaturated fatty acids. On the other hand, OC flour had higher percentages of polyunsaturated fatty acids, especially omega- 3 and omega- 6 fatty acids, ash and carbohydrates. The results demonstrated good nutritional potential for flour from grape bagasse and justified technological applications of the byproduct as a functional ingredient in the formulation of food products.
\end{abstract}

Key words: Bioactive compound, byproduct, grape bagasse, lipid quality.

\section{Introduction}

Grapes (Vitis spp), the fruit of the grape vine, are among the most ancient foods known to mankind with more than 10,000 varieties worldwide. Brazil currently produces approximately 1.2 million tons of grapes per year, of which $45 \%$ is transformed into wine and juices and jellies, and $20 \%$ is waste byproduct. Grape bagasse, a solid waste retrieved from grape processing, comprises the solid parts of the grapes as well as the must, which is rich

Received January 29, 2014. Accepted July 14, 2014. Corresponding author: ivane@utfpr.edu.br in sugars, proteins and unsaturated fatty acids (Perestrelo et al., 2012).

The transformation of grape bagasse into flour may be a viable alternative for the reutilization of the byproduct (Sáyago-Ayerdi et al., 2009), which may be used in the production of hamburgers and sausages (Özvural and Vural, 2011) and inserted into yogurts (Coda et al., 2012) and salad dressings (Tseng and Zhao, 2013). Grape bagasse flour contains high amounts of flavonoids, which are excellent antioxidants that reduce free radicals and prevent degenerative diseases. 
A study by Perestrelo et al. (2012) has described the phenolic profile of different grape varieties as being characterized by 40 phenolic compounds. That study contributed towards the valorization of the fruit as a source of bioactive substances. The authors revealed that natural and processed grapes are an important source of biologically active compounds and are highly beneficial to health. Additionally, not only do these grapes have antioxidant potential but they also have antiallergenic, antiarteriogenic, anti-inflammatory, antimicrobial and antithrombosis pharmacological traits as well as heart-protecting properties.

Although Vitis labrusca, one of the cultivars produced in Brazil, is known for its hardiness and resistance to fungal diseases, agrochemicals have been applied to the vine due to climate oscillations and to its vulnerability to biological onslaughts. Continuous application of agrochemicals may affect consumers' health and well-being through the accumulation of products manufactured from copper (Bordeaux mixture) and of synthetic and organic fungicides in the soil (Perestrelo et al., 2012).

On the other hand, cultivation with organic manure has been recommended by Coda et al. (2012) as a sustainable alternative for the possible production of grapes without any chemical residues. Therefore, health risks to the consumer are largely decreased. Although no conclusive studies exist that prove the nutritional gains from organic food, consumers already associate consumption of organic foods with low exposure to agrochemicals and with better health.

The current study analyzes the nutritional and lipid quality of grape bagasse flour obtained by drying and retrieved from conventional and organic production. This study evaluates proximal composition, fatty acid profile, nutritional quality indexes of lipids and the presence of biologically active compounds in the two different flour types.

\section{Material and methods}

\section{Samples}

Vitis labrusca cv. 'Concord' grapes produced in two vineyards, each 10 years old using either conventional or organic systems, were used for the production of grape bagasse flour. The flour was from the 2011-2012 harvest in the Verê PR Brazil municipality. The vineyards were located in the same region. The conventional production vineyard had a $564 \mathrm{~m}$ altitude with a latitude of $25^{\circ} 54^{\prime} 01^{\prime \prime} \mathrm{S}$ and longitude of $52^{\circ} 53^{\prime} 51^{\prime \prime} \mathrm{W}$, and the organic vineyard had an altitude of 492 $\mathrm{m}$, a latitude of $25^{\circ} 51^{\prime} 21^{\prime \prime} \mathrm{S}$ and a longitude of $52^{\circ} 55^{\prime} 06$ ' W. The properties are within $5.3 \mathrm{~km}$ of each other and are therefore under similar climatic conditions.

The residue used in the production of grape flour was collected in a juice facility located in the same region as the vineyards. For the study, we used approximately $50 \mathrm{~kg}$ of grape residue (skins and seeds), which included $25 \mathrm{~kg}$ from the organic system and $25 \mathrm{~kg}$ from the conventional system.

The grape wastes were dried in an air muffle at $60{ }^{\circ} \mathrm{C}$ for 7 days. After cooling, the dry waste was ground in a food processor and sieved in $20-50$ mesh sieves at room temperature in the dark. Approximately $7.0 \mathrm{~kg}$ of flour from each mode of cultivation was vacuum packed and stored until analysis.

\section{Preparation of extracts}

The extracts were obtained by cold hydroalcoholic extraction. From each sample, $60 \mathrm{~g}$ of the extracts were homogenized in $60 \mathrm{~mL}$ of $80 \%$ ethanol (Merck, Darmstadt/Germany) in a mixer for 10 min. After wards, the samples were centrifuged at $3500 \mathrm{rpm}$ for $20 \mathrm{~min}$. An additional $60 \mathrm{~mL}$ of $80 \%$ ethanol was added to the precipitate to obtain a new extract. The new extract was mixed for 10 
min and subsequently centrifuged for $20 \mathrm{~min}$. The same procedure was repeated once more. All supernatants were pooled to create a single hydroalcoholic extract per sample. The extracts were kept at $-18{ }^{\circ} \mathrm{C}$ until analysis.

\section{Physical and chemical analyses}

Percentage of moisture, ash, proteins, total lipids, carbohydrates and caloric. Moisture, ash and protein percentages were determined by methodologies following the AOAC (2008). Total lipids were calculated by gravimeter following Bligh and Dyer (1959). The carbohydrate percentage was obtained by calculating the difference between $100 \%$ and the sum of protein, lipid, moisture and ash percentages (Instituto Adolpho Lutz, 2008), whereas calories were the sum of carbohydrate and protein percentages multiplied by four and the lipid percentages multiplied by nine according to coefficients from Atwater (Tagle, 1981).

\section{Lipid transesterification and determination of} fatty acids. Total lipid transesterification was performed following method 5509 of the International Organization for Standardization (1978). Fatty acids were determined by analyzing esters with a gas chromatograph 431-GC (Varian, Inc. Walnut Creek/USA) equipped with a 210-MS mass detector of the same trademark and a VF-5 $\mathrm{ms}$ fused-silica capillary column $(30 \mathrm{~m}, 0.25 \mathrm{~mm}$, $0.25 \mu \mathrm{m})$. Column temperature was programmed at $8{ }^{\circ} \mathrm{C} \mathrm{min}-1$ from $100{ }^{\circ} \mathrm{C}$ to $250{ }^{\circ} \mathrm{C}$. Gas flow (He) was kept at $1.0 \mathrm{~mL} \mathrm{~min}^{-1}$, and the split ratio was $1 / 50$. Fatty acids were identified by comparing the fatty acid methyl ester (FAME) peaks' relative retention times from each sample with methyl ester standards of fatty acids (Supelco/ Sigma-Aldrich, São Paulo/Brazil).

Indexes of lipid nutritional quality (INQ). The nutritional quality of the lipid fraction of samples of grape bagasse flour was determined by examining the fatty acid profile and taking into consideration three indexes: atherogenicity (AI), thrombogenicity
(TI) and the ratio between hypocholesterolemic and hypercholesterolemic fatty acids (HH). The following calculations were employed:

a) Atherogenicity Index

$(\mathrm{AI})=[(\mathrm{C} 12: 0+4 \times \mathrm{C} 14: 0+\mathrm{C} 16: 0)] /(\Sigma \mathrm{AGMI}+$ $\left.\Sigma \mathrm{n}-6+\sum \mathrm{n}-3\right)$

b) Thrombogenicity Index

$(\mathrm{TI})=(\mathrm{C} 14: 0+\mathrm{C} 16: 0+\mathrm{C} 18: 0) /$ $[(0,5 \times \Sigma$ AGMI $)+(0,5 \times \Sigma \mathrm{n}-6)+(3 \times \Sigma \mathrm{n}-3)+(\Sigma \mathrm{n}-3 / \mathrm{n}-6)]$

c) Ratio of hypocholesterolemic and hypercholesterolemic fatty acids

$(\mathrm{HH})=(\mathrm{C} 18: 1 \mathrm{n}-9+\mathrm{C} 18: 2 \mathrm{n}-6+\mathrm{C} 20: 4 \mathrm{n}-6+\mathrm{C} 18: 3 \mathrm{n}-3-$ $+\mathrm{C} 20: 5 \mathrm{n}-3+\mathrm{C} 22: 5 \mathrm{n}-3+\mathrm{C} 22: 6 \mathrm{n}-3) /(\mathrm{C} 14: 0+\mathrm{C} 16: 0)$

Antioxidant activity. Antioxidant activity was determined by the DPPH method (2,2-diphenyl1-picryl-hidrazila). An aliquot of $0.1 \mathrm{~mL}$ of the samples was transferred to test tubes with 3.9 $\mathrm{mL}$ of DPPH and $0.1 \mathrm{~mL}$ of the control solution of methyl alcohol (Merck, Darmstadt/Germany), acetone (Merck, Darmstadt/Germany) and water. Then, homogenization was performed in shaker tubes. Readings of absorbance in a spectrophotometer (spectrophotometer UV-VIS, Femto model 800X, São Paulo/Brazil) at $515 \mathrm{~nm}$ were carried out after $30 \mathrm{~min}$ of reaction time. The reaction time was established through previous tests ranging from $30 \mathrm{~min}$ to $24 \mathrm{~h}$. Quantification was based on establishing a standard curve in concentrations of 10,20,30,40, 50 and 60 $\mathrm{mM}$, from an initial DPPH solution $(60 \mathrm{mM})$. The results were expressed as EC50 ( $\mathrm{g}$ flour $\mathrm{g}^{-1}$ $\mathrm{DPPH})$. The obtained values correspond to the amount of sample required to reduce by $50 \%$ the initial concentration of DPPH. Additionally, we determined the free radical scavenging activity from a standard curve of Trolox (6- hydroxy -2,5,7,8- tetramethylchromane 2- carboxylic acid) (Fluka/Sigma-Aldrich, WGK/Germany). Different solutions $(0.1,0.5,1.0,2.0$ and $3.0 \mathrm{mM})$ 
were prepared from an initial Trolox solution (20 $\mathrm{mM}$ ). Each concentration was transferred to 20 , 100, 200, 300 and $600 \mathrm{~mL}$ test tubes, and $4 \mathrm{~mL}$ of the DPPH solution was added. The test tubes were shaken and read in a spectrophotometer at $515 \mathrm{~nm}$ after $30 \mathrm{~min}$ of reaction time. The results were expressed as Trolox equivalent antioxidant activity (TEAC, $\mu \mathrm{mol}$ of trolox $\mathrm{g}^{-1}$ flour).

Determination of total phenolic content. Total phenolic content was determined using FolinCiocalteau (FC) reagent (BDH Ltd, Radnor/ Pennsylvania). In a 100-mL-graduated flask, 1 $\mathrm{mL}$ of extract from each sample was added to 60 $\mathrm{mL}$ of ultra pure water and $5 \mathrm{~mL}$ of Folin reagent. After $8 \mathrm{~min}, 20 \mathrm{~mL}$ of $20 \%$ sodium carbonate was added and the volume was completed with distilled water and kept at rest and in the dark for $2 \mathrm{~h}$. The solution was later filtered in a $250 \mathrm{~mL}$ graduated flask and topped with distilled water. The measurement of the solutions was performed with a spectrophotometer at $725 \mathrm{~nm}$. A control sample was prepared by substituting $1 \mathrm{~mL}$ of the extract for $1 \mathrm{~mL}$ of distilled water. A straight line equation was obtained by a calibration curve with different concentrations of gallic acid. Data were applied to the straight line equation by stoichiometry for dilutions, with the results given in $\mathrm{mg}$ of gallic acid per gram of sample.

Total anthocyanins. Total anthocyanins were evaluated by spectrophotometry (spectrophotometer UV-VIS, Femto model 800X, São Paulo/Brazil) following methods described in Fuleki and Francis (1968). Two buffer solutions with $\mathrm{pH} 1.0$ and $\mathrm{pH}$ 4.5 were prepared. Adequate dilution for each flour sample (1 mL extract) was determined by diluting the sample with buffer solutions at $\mathrm{pH}$ 1.0 and 4.5. Measurements of the samples were undertaken at 520 and $700 \mathrm{~nm}$.

Total anthocyanins were obtained according to the following equation:

$(\mathrm{A} \times \mathrm{MW} \times \mathrm{DF} \times 103) /(\varepsilon \times \mathrm{I})=$ equivalent cyanidin-3-glucoside, $\mathrm{mg} \mathrm{L}^{-1}$, where:

$\mathrm{A}=(\mathrm{A} 520 \mathrm{~nm}-\mathrm{A} 700 \mathrm{~nm}) \mathrm{pH} 1-(\mathrm{A} 520 \mathrm{~nm}-\mathrm{A} 700$ nm) $\mathrm{pH} 4.5$; $\mathrm{MW}=449.2 \mathrm{~g} \mathrm{~mol}^{-1}$ by cyanidin-3-glucoside; $\mathrm{DF}=$ dilution factor established in $\mathrm{D}$; $\mathrm{I}=$ optic pathway in $\mathrm{cm}$; $\varepsilon=26.900$ coefficient of molar extinction.

\section{Statistical analysis}

All data were expressed as the means \pm standard deviation. All measurements were replicated three times. The data were standardized by the equation $x-\bar{x} / s$, where $x$ is the observed value, $\bar{x}$ is the average of three replicates and $s$ is the standard deviation. This procedure was necessary because there was no normality among most data. The results were subjected to an analysis of variance using a statistical significance threshold of $5 \%$, and significantly different means were furthered tested using Tukey's test with Statistica 7.0 (Statsoft Inc, 2004).

\section{Results and discussion}

Table 1 shows the percentage of parameters analyzed for the proximal composition and caloric characteristics of Concord grape bagasse flour from conventional and organic cultures.

The results showed that the moisture, ash, protein, lipid, carbohydrate and caloric values in flour from the conventional culture (CC) were significantly different $(\mathrm{P} \leq 0.05)$ from the values in flour from the organic culture grapes (OC). As a rule, flour from the $\mathrm{CC}$ had higher moisture, protein, and lipid percentages and also a higher caloric index compared to those in the OC grape bagasse flour. The latter contained higher percentages of carbohydrates and minerals (ash).

Because the moisture contents were lower than $12.0 \%$, they complied with the Brazilian legislation on quality parameters for cereal, starch, flour 
Table 1. Physical and chemical characterization of grape bagasse flour in conventional and organic culture systems obtained by muffle drying.

\begin{tabular}{lcc}
\hline & \multicolumn{2}{c}{ Grape bagasse flour } \\
\cline { 2 - 3 } & $\begin{array}{c}\text { Conventional } \\
\text { culture (CC) } \\
\text { Parameters }\end{array}$ & $\begin{array}{c}\text { Organic culture } \\
(\text { OC) } \\
(\% \pm \text { d.p })\end{array}$ \\
\hline Moisture (\%) & $9.86 \pm 0.10 \mathrm{~b}$ & $8.99 \pm 0.06 \mathrm{a}$ \\
Ash (\%) & $1.90 \pm 0.03 \mathrm{a}$ & $2.04 \pm 0.02 \mathrm{~b}$ \\
Protein (\%) & $6.54 \pm 0.08 \mathrm{~b}$ & $5.20 \pm 0.29 \mathrm{a}$ \\
Lipids (\%) & $5.10 \pm 0.05 \mathrm{~b}$ & $3.62 \pm 0.04 \mathrm{a}$ \\
Carbohydrate (\%) & $76.60 \pm 0.11 \mathrm{a}$ & $80.15 \pm 0.32 \mathrm{~b}$ \\
Caloric value (Kcal) & $378.45 \pm 0.40 \mathrm{~b}$ & $374.00 \pm 0.33 \mathrm{a}$ \\
\hline
\end{tabular}

Results are the mean of three replicates with their standard deviation estimates. Values on the same line followed by same letters do not differ $(\mathrm{P}>0.05)$. (Analysis of variance - ANOVA and Tukey's test). CC: conventional culture; CO: organic culture.

and grain products. The variation in moisture may have been caused by the different types of grape culture because the same technological process was employed for both types of flour.

A significant difference $(\mathrm{P} \leq 0.05)$ was also reported between the ash percentages in the samples of grape bagasse flour from the conventional culture $(1.90 \%)$ and the organic culture (2.04\%). According to the Brazilian Institute of Wines, the percentage of ash in grape flour samples derived from OC may have been caused by higher mineralogical availability in the soil of OC and by variations in soil, climate, irrigation methods and fertilization. In their study of the 'Rubi', 'Niágara' and 'Brasil' grape varieties, Souza et al. (2011) reported ash percentages between 0.43 and $2.11 \%$ in the peel and between 0.39 and $1.10 \%$ in the pulp. These values were close to those in the current study.

The percentage of protein in the CC grape bagasse flour was $6.54 \%$, whereas the percentage was $5.20 \%$ in the OC; these values represented a significant difference $(\mathrm{P} \leq 0.05)$ between the cultures. Likewise, Bampi et al. (2010) found $5.73 \%$ protein in the flour of the oriental raisin (Hovenia dulcis).

The lipid percentages in the $\mathrm{CC}$ and $\mathrm{OC}$ grape bagasse flour varied between $3.62 \%$ and $5.10 \%$, which was a significant difference $(\mathrm{P} \leq 0.05)$ between the cultures. These results were higher than the lipid content $(1.82 \%)$ of flour from the oriental raisin reported by Bampi et al. (2010).

The carbohydrate percentage $(80.15 \%)$ of OC grape bagasse flour was significantly higher compared to the percentage of the conventional treatment sample $(76.60 \%)$. The differences in the carbohydrate percentages between the types of flour assessed may be due to the acceleration of vegetal cell metabolism during the OC cultivar's development. In fact, a grape's chemical composition is defined by maturation stage, genetic potential, climate and management.

The results for the caloric content of the two types of flour under analysis showed that the $\mathrm{CC}$ grape bagasse flour (378.45 Kcal) had significantly more calories compared to the OC flour $(374.00 \mathrm{Kcal}$, $\mathrm{P} \leq 0.05)$. Bampi et al. (2010) reported a caloric content of $216.09 \mathrm{Kcal}$ for flour from table grape bagasse. The caloric content in the current study was similar to those found by the previously mentioned researchers.

Table 2 shows the sum and ratio of fatty acids in samples obtained by muffle drying the Concord grape bagasse flour from the two cultures.

Table 2 shows that the lipid profile, sum and PUFA/SFA ratio differed significantly $(\mathrm{P} \leq 0.05)$ for the conventional and organic cultured grape bagasse flour, whereas the $n-6 / n-3$ ratio was not significantly different $(\mathrm{P}>0.05)$ between the samples. There were five saturated, six monounsaturated and four polyunsaturated fatty acids in the Concord grape bagasse flour samples from the conventional and organic cultures.

The prevalent fatty acids in the lipid fraction of the grape bagasse flour derived from the conventional culture system were linoleic acid (18:2n-6, 25.77\%), paulinic acid (20:1n-7, 14.19\%), cis-vaccenic acid (18:1n-7, 10.61\%), gondoic acid (20:1n-9, 10.15\%) and margaric acid (17:0, 7.11\%). These fatty acids were predominant in grape 
Table 2. Composition, sum and ratio of fatty acids in samples of Concord grape flour conventionally and organically cultivated and muffle-dried.

\begin{tabular}{lcc}
\hline & \multicolumn{2}{c}{ Grape bagasse flour } \\
\cline { 2 - 3 } Fatty Acids & $\begin{array}{c}\text { Conventional culture } \\
(\text { CC) }\end{array}$ & $\begin{array}{c}\text { Organic culture } \\
(\text { OC })\end{array}$ \\
\hline $12: 0$ & $5.66 \pm 0.01 \mathrm{~b}$ & $3.13 \pm 0.01 \mathrm{a}$ \\
$14: 0$ & $3.14 \pm 0.01 \mathrm{~b}$ & $2.16 \pm 0.01 \mathrm{a}$ \\
$15: 0$ & $0.94 \pm 0.01 \mathrm{a}$ & $3.41 \pm 0.02 \mathrm{~b}$ \\
$16: 0$ & $6.11 \pm 0.02 \mathrm{~b}$ & $0.76 \pm 0.01 \mathrm{a}$ \\
$17: 0$ & $7.11 \pm 0.02 \mathrm{a}$ & $8.06 \pm 0.02 \mathrm{~b}$ \\
$\sum$-SFA & $22.96 \pm 0.01 \mathrm{~b}$ & $17.52 \pm 0.01 \mathrm{a}$ \\
$16: 1 \mathrm{n}-5$ & $1.29 \pm 0.02 \mathrm{~b}$ & $1.28 \pm 0.02 \mathrm{a}$ \\
$17: 1 \mathrm{n}-9$ & $6.76 \pm 0.01 \mathrm{~b}$ & $5.63 \pm 0.01 \mathrm{a}$ \\
$18: 1 \mathrm{n}-9$ & $4.04 \pm 0.01 \mathrm{a}$ & $5.01 \pm 0.01 \mathrm{~b}$ \\
$18: 1 \mathrm{n}-7$ & $10.61 \pm 0.01 \mathrm{a}$ & $14.43 \pm 0.01 \mathrm{~b}$ \\
$20: 1 \mathrm{n}-9$ & $10.15 \pm 0.02 \mathrm{a}$ & $11.02 \pm 0.02 \mathrm{~b}$ \\
$20: 1 \mathrm{n}-7$ & $14.19 \pm 0.02 \mathrm{~b}$ & $11.02 \pm 0.02 \mathrm{a}$ \\
$\sum$-MUFA & $47.04 \pm 0.01 \mathrm{~b}$ & $34.09 \pm 0.01 \mathrm{a}$ \\
$18: 2 \mathrm{n}-6$ & $25.77 \pm 0.01 \mathrm{a}$ & $27.70 \pm 0.02 \mathrm{~b}$ \\
$18: 3 \mathrm{n}-6$ & $1.00 \pm 0.02 \mathrm{a}$ & $2.71 \pm 0.01 \mathrm{~b}$ \\
$18: 3 \mathrm{n}-3$ & $3.23 \pm 0.02 \mathrm{a}$ & $3.68 \pm 0.01 \mathrm{~b}$ \\
$\sum$-PUFA & $30.00 \pm 0.01 \mathrm{a}$ & $48.39 \pm 0.01 \mathrm{~b}$ \\
$\sum$-n-6 & $26.77 \pm 0.01 \mathrm{a}$ & $30.41 \pm 0.01 \mathrm{~b}$ \\
$\sum$-n-3 & $3.23 \pm 0.01 \mathrm{a}$ & $3.68 \pm 0.01 \mathrm{~b}$ \\
Rate & & \\
PUFA/SFA & $1.31 \pm 0.01 \mathrm{a}$ & $2.76 \pm 0.01 \mathrm{~b}$ \\
$\mathrm{n}-6 / \mathrm{n}-3$ & $8.29 \pm 0.01 \mathrm{a}$ & $8.26 \pm 0.01 \mathrm{a}$ \\
\hline Resuts & &
\end{tabular}

Results are the mean of two replications in percentages with estimates of standard deviation. Values on the same line followed by same letters do not differ $(\mathrm{P}>0.05)$. (Analysis of variance - ANOVA and Tukey's test). CC: Conventional culture. CO: Organic culture. SFA: saturated fatty acids. MUFA: monounsaturated fatty acids. PUFA: polyunsaturated fatty acids (unsaturation $\geq 2$ ). n-6: omega-6 fatty acids. n-3: omega-3 fatty acids. PUFA/SFA: ratio between polyunsaturated and saturated fatty acids. n-6/n-3: ratio between omega- 6 and omega- 3 fatty acids.

bagasse flour derived from the organic culture system, with mean percentages of $27.70 \%, 14.43 \%$, $11.02 \%$ and $8.06 \%$ for linoleic acid (18:2n-6), cisvaccenic acid (18:1n-7), paulinic acid (20:1n-7), gondoic acid (20:1n-9) and margaric acid (17:0), respectively.

Lutterodt et al. (2011) underscored that, similar to data from current investigation, the linoleic acid percentage (18:2n-6) was higher (66.0 to $75.3 \%$ ) than the other fatty acids of the oils and seed flours from various grape species. The authors reported that flour had up to 100 times more phenolic compounds than oils.
The composition of fatty acids in grape bagasse flour is similar to that of sunflower, soybean, maize and cotton seed oil. The fatty acid levels of the CC and OC grape bagasse flours were lower than those reported by Göktürk-Baydar et al. (2007) for the seed oils of the Ancelota, Tannat, Regente, Pinot Noir, Bordeaux, Merlot, Isabel and Cabernet Sauvignon grape varieties, which had percentages of linoleic acid (18:2n-6) varying between $47.63 \%$ (Cabernet Sauvignon) and $60.02 \%$ (Merlot). In fact, they were higher than those in the current analysis.

It is important to note that the evaluation by the abovementioned authors referred to oils with high concentrations of fatty acids, whereas the types of flour from a byproduct (grape bagasse) of grape processing were the focus of the current study. The latter had a differentiated composition.

Linoleic (LA, 18:2n-6) and alpha-linolenic (LNA, 18:3n-3) acids are required by the human body for the maintenance of cell membranes, brain function and the transmission of nervous impulses in normal conditions. These essential fatty acids also participate in the transference of atmospheric oxygen to the blood, in hemoglobin synthesis and in cell division (Lutterodt et al., 2011).

Saturated fatty acids (SFA) comprised $22.95 \%$ and $17.5 \%$ of CC and OC grape bagasse flour, respectively, and thus differed significantly $(\mathrm{P} \leq 0.05)$. The MUFA and PUFA sums were $47.04 \%$ and $30.00 \%$ for samples of CC grape flour, differing significantly $(\mathrm{P} \leq 0.05)$ from $\mathrm{OC}$ samples, which had $34.09 \%$ MUFA and 48.39 PUFA content. Fernandes et al. (2013) reported percentages between $11.64 \%$ and $14.94 \%$, between $14.19 \%$ and $21.29 \%$ and between $63.64 \%$ and $73.53 \%$ for SFA, MUFA and PUFA, respectively, in grape seed oil, which were different from the values obtained in the current study.

LNA and LA polyunsaturated fatty acids are present in vegetal and animal species and are used in human food. They are highly important in 
nutritional terms due to their status as precursors of the other fatty acids of the n-3 and n- 6 series. The same researchers also reported that LNA was found in vegetables, especially those with dark green leaves, although its concentration depended on the species and seasonal factors.

The PUFA/SFA ratio of CC grape bagasse flour, 1.31 , differed significantly $(\mathrm{P} \leq 0.05)$ from the 2.76 ratio obtained from the bagasse flour of the same grape cultivated by the OC system. According to the Department of Health and Social Security, eating food with a PUFA/SFA ratio lower than 0.45 was not recommended due to a trend towards increasing blood cholesterol. Grape bagasse flour from organic and conventional cultures was acceptable according to the suggested minimum ratio.

The samples were statistically equivalent $(\mathrm{P}>0.05)$ in their $n-6 / n-3$ ratios of 8.28 and 8.26 for $\mathrm{CC}$ and OC grape bagasse flour, respectively.

Ratios between 5:1 and 10:1 are recommended by the WHO and FAO. However, diets based on n-6/n-3 ratios lower than 1:1 are not recommended because they inhibit the transformation of linoleic acid into longer chain polyunsaturated fatty acids.

Garde-Cerdán et al. (2007) found that the composition of fatty acids and free amino-acids of grape juices remained stable even after thermal treatments. It may be inferred that the thermal treatment of grape bagasse flour does not interfere significantly with the final product's fatty acid and protein composition.

The fatty acid profiles also enabled the evaluation of the lipid fraction's nutritional quality index. The atherogenicity (AI) and thrombogenicity (TI) indexes and the ratios of hypocholesterolemic and hypercholesterolemic fatty acids ( $\mathrm{HH}$ ) could therefore be determined.

According to Turan et al. (2007), nutritional quality indexes can indicate a sample's potential for plaque aggregation. In other words, low AI and TI values indicate high quantities of anti-atherogenic fatty acids in oil or fat.

Table 3 shows the evaluation of the nutritional quality of the lipid fractions of the grape bagasse flour from conventional and organic culture systems, as determined by the atherogenicity (AI) and thrombogenicity (TI) indexes and the ratios of hypocholesterolemic and hypercholesterolemic fatty acids $(\mathrm{HH})$.

Table 3. Indexes of the nutritional quality of the lipid fraction of grape bagasse flour from organic and conventional culture obtained by muffle drying.

\begin{tabular}{lcc}
\hline & \multicolumn{2}{c}{ Grape bagasse flour } \\
\cline { 2 - 3 } Index & $\begin{array}{c}\text { Conventional } \\
\text { culture (CC) }\end{array}$ & Organic culture (OC) \\
\hline AI & 0.32 & 0.18 \\
TI & 0.17 & 0.06 \\
HH & 3.57 & 12.46 \\
\hline
\end{tabular}

AI: atherogenicity index; TI: thrombogenicity index; $\mathrm{HH}$ : ratio between hypocholesterolemic and hypercholesterolemic fatty acids.

The atherogenicity (AI) and thrombogenicity (TI) indexes had higher values, 0.32 and 0.17 , respectively, for grape bagasse flour from conventional cultures, whereas the ratios between hypocholesterolemic and hypercholesterolemic fatty acids $(\mathrm{HH})$ were higher in grape bagasse flour derived from OC (12.46).

The values for the three indexes (AI, TI and $\mathrm{HH}$ ) showed that grape bagasse flour derived from $\mathrm{CC}$ and $\mathrm{OC}$ had beneficial effects on health. The lower the atherogenicity (AI) and thrombogenicity (TI) index values, the healthier the food. This is because these indexes report the relationship between fatty acids in food and their contribution to the prevention of coronary diseases (Turan et al., 2007). Further, Souza Bentes et al. (2009) underscored that oil or fat was nutritionally the most adequate based on the relation between hypocholesterolemic and hypercholesterolemic fatty acids. 
In the current study, $\mathrm{HH}$ ratios of 3.57 and 12.46 were found for the $\mathrm{CC}$ and $\mathrm{OC}$ grape bagasse flour, respectively. These ratios indicate the nutritional adequacy, with an indication of greater quality for the OC flour. In their analysis of Syagrus oleracea (guarirova), Nozaki et al. (2012) reported higher $\mathrm{AI}$ and TI values than in the present study. The authors registered atherogenicity indexes at 0.69 and 11.53 and thrombogenicity indexes at 1.32 and 4.82 for pulp and kernel oils, respectively, and an $\mathrm{HH}$ ratio of 1.39 for pulp oil and 0.40 for kernel oil.

According to Rockenbach et al. (2008), bioactive compounds, such as anthocyanins and other flavonoids, are highly beneficial to health, especially due to their activities against free radicals, allergies, inflammations, ulcers, viruses, tumors and hepatotoxins.

Table 4 shows the results of the analyses of the bioactive compounds from grape bagasse flour dried in a muffle.

Of the analyzed bioactive compounds, only the OC flour phenolic compound content was significantly higher $(\mathrm{P} \leq 0.05)$ than those of the conventional system. The other parameters failed to differ statistically $(\mathrm{P}>0.05)$.

The anthocyanin content in the current study was higher than that reported by Rockenbach et al. (2008) in samples from extracts of grape bagasse from the Ancelota and Tanna varieties, which had concentrations between 0.13 and $1.95\left({\mathrm{~g} 100 \mathrm{~g}^{-1}}^{-1}\right.$ dry weight) and between 0.04 and $0.77\left({\mathrm{~g} 100 \mathrm{~g}^{-1}}^{-1}\right.$ dry weight), respectively. Exogenous treatments with UV-C, simulating abiotic stress, undertaken by Pala and Toklucu (2012) in grape juice, failed to show any significant differences $(\mathrm{P}>0.05)$ in the phenolic compound content.

In the current analysis, total phenolic compound content was significantly higher in the OC Concord grape flour. The production system is a factor that may interfere with the content of total
Table 4. Bioactive compounds of Concord grape flour samples obtained from conventional and organic production systems dried in a muffle.

\begin{tabular}{lcc}
\hline & \multicolumn{2}{c}{ Grape bagasse flour } \\
\cline { 2 - 3 } Bioactive Compounds & $\begin{array}{c}\text { Conventional } \\
\text { culture }(C C)\end{array}$ & $\begin{array}{c}\text { Organic culture } \\
(\mathrm{OC})\end{array}$ \\
\hline Total Anthocyanins & \\
Total Phenolic & $96.31 \pm 3.60 \mathrm{a}$ & $97.13 \pm 3.80 \mathrm{a}$ \\
compounds $^{2}$ & $173.82 \pm 4.20 \mathrm{a}$ & $215.64 \pm 3.80 \mathrm{~b}$ \\
Antioxidant activity $_{\text {EC50 }}{ }^{3}$ & & \\
TEAC $^{4}$ & $357.16 \pm 7.00 \mathrm{a}$ & $341.77 \pm 7.60 \mathrm{a}$ \\
\hline
\end{tabular}

Results are the mean of three replications with the estimates for standard deviation. Values on the same line followed by the same letters do not differ $(\mathrm{P}>0.05)$. (Analysis of variance - ANOVA and Tukey's test). CC: conventional culture. OC: organic culture. ${ }^{1} \mathrm{mg}$ of cyanidin-3-glucoside $100 \mathrm{~g} \mathrm{~g}^{-1}$ flour; ${ }^{2} \mathrm{mg} \mathrm{GAE} \mathrm{g}{ }^{-1}$ flour; ${ }^{3} \mathrm{~g}$ flour $\mathrm{g}^{-1} \mathrm{DPPH} ;{ }^{4} \mu \mathrm{mol}$ of trolox $\mathrm{g}^{-1}$ flour.

phenolic compounds and consequently with the flour retrieved from their waste.

Several researchers report that the bioactive compound content in fruit may be affected by the culture system with the development of defense systems against the fruits' natural pests (López et al., 2013). Freitas et al. (2010) state that an increase in the concentration of the grape's phenolic compounds is related to the plant's own defense system. Investigations by Melo et al. (2011) on Verdejo and Isabel grape bagasse found phenolic compound indexes (dry weight) of $20.94 \mathrm{mg}$ gallic acid $\mathrm{g}^{-1}$ and $16.57 \mathrm{mg}$ gallic acid g-1 ${ }^{-1}$ respectively. Rockenbach et al. (2008) reported $75.6 \mathrm{mg}$ gallic acid $\mathrm{g}^{-1}$ for Ancelota grape bagasse and $69.0 \mathrm{mg}$ gallic acid $\mathrm{g}^{-1}$ for Tannat grape bagasse. The results showed that the natural defense systems developed by plants triggered bioactive compounds with beneficial health traits associated with the prevention and control of diseases in humans.

The antioxidant activity of flour from CC and OC was not significantly affected by the production system. Mulero et al. (2010) described higher antioxidant activity in OC grapes, which, according to the researchers, was directly related to the accumulation of phenolic compounds. In 
the current study, a significant co-relationship between phenolic compounds and antioxidant activity could not be demonstrated. However, based on the reports of the authors mentioned above, the organic system's influence may be possible due to the higher content of phenolic compounds.

\section{Acknowledgments}

The authors thank the Fundação Araucária, Conselho Nacional de Desenvolvimento Científico e Tecnológico (CNPq-Brasil) and the Support Program for the publication of Universidade Tecnológica Federal do Paraná (UTFPR) - Francisco Beltrão.

\section{Resumen}

L.D. Lopes, B.R. Böger, K.F. Cavalli, J.F. dos S. Silveira-Júnior, D.V.C.L. Osório, D.F. de Oliveira; L. Luchetta y I.B. Tonial. 2014. Perfil de los ácidos grasos, índices de calidad de los lípidos y compuestos bioactivos de las harinas de residuos de la uva. Cien. Inv. Agr. 41(2): 225-234. Los alimentos producidos con el uso de los subproductos, caracterizados por propiedades bioquímicas y fisiológicas beneficiosas para salud y porque evitan una mayor degradación del medio ambiente, han sido bastante discutidos y valorados. El estudio evaluó la composición proximal, perfil de ácidos grasos, los índices de la calidad nutricional de los lípidos y la presencia de compuestos biológicamente activos en las harinas de orujo de uvas a partir del métodos de cultivo: convencional (CC) y orgánico (CO). Los resultados mostraron que la harina CC mostró altos niveles de proteínas, grasas, calorías, ácidos grasos saturados y monoinsaturados, mientras que el contenido en ácidos grasos poliinsaturados, especialmente omega-3 y omega-6, los carbohidratos y las cenizas fueron mayores para la harina CO. Estos resultados indican un bueno potencial nutricional de la harina obtenida de orujo de uva, así justifican la aplicación tecnológica del subproducto como un ingrediente funcional en la formulación de productos alimenticios.

Palabras clave: Calidad de lípidos, compuestos bioactivos, orujo de uva, subproducto.

\section{References}

AOAC-Association of Official Analytical Chemists. 2008 - Official methods of analysis. 18th ed. Gaitherburg.

Bampi, M., M.O.P. Bicudo, P.S.G. Fontoura, R. H. Ribani. 2010. Composição centesimal do fruto, extrato concentrado e da farinha da uva-do-japão. Ciência Rural 40: 2361-2367.

Bligh, E.G., W. J.Dyer. 1959. A rapid method of total lipid extraction and purification. Canadian Journal Chemistry 37:911-917.

Coda, R., A. Lanera, A.Trani, M.,Gobbetti, and R. Di Cagno. 2012. Yogurt-like beverages made of a mixture of cereals, soy and grape must: Micro- biology, texture, nutritional and sensory properties. International Journal Food Microbiological 155:120-127.

Fernandes, L., S. Casal, R. Cruz, J.A. Pereira, and E. Ramalhosa. 2013. Seed oils of ten traditional Portuguese grape varieties with interesting chemical and antioxidant properties. Food Research International 50:161-166.

Freitas, A.A., A.M.C. Detoni, and C.C. Oliveira. 2010. Determinação de resveratrol e características químicas em sucos de uvas produzidas em sistemas orgânico e convencional. Revista Ceres 57:001-005.

Fuleki, T., and F.J. Francis. 1968. Quantitative determination of anthocyanins. Determination of total 
anthocyanins and degradation index for cranberry juice. Journal Food Science 33:78-83.

Garde-Cerdán, T., M. Arias-Gil, A.R. Marsellés-Fontanet, C. Ancín-Azpilicueta, and O. Martín-Belloso. 2007. Effects of thermal and non-thermal processing treatments onfatty acids and free aminoacids of grape juice. Food Control 18:473-479.

Göktürk-Baydar, N., G. Özkan, and E.S. Çetin. 2007. Characterization of grape seed and pomace oil extracts. Grasas Aceites 58: 29-33.

Instituto Adolpho Lutz. 2008. Normas Analíticas do Instituto Adolpho Lutz: Métodos Químicos para Análise de Alimentos. 4.ed. São Paulo: Instituto Adolpho Lutz (IAL).

López, A., J. Fenoll, P. Hellín, AND P. Flores. 2013. Physical characteristics and mineral composition of two pepper cultivars under organic, conventional and soilless cultivation. Science and Horticulture 150:259-266.

Lutterodt, H., M. Slavin, M. Whent, E. Turner, and L.L. Yu. 2011. Fatty acid composition, oxidative stability, antioxidant and antiproliferative properties of selected cold-pressed grape seed oils and flours. Food Chemistry 128:391-399.

Melo, P. S., K.B. Bergamaschi, A.P. Tiveron, A.P. Massarioli, T.L.C. Oldoni, M.C. Zanus, G.E. Pereira, and S.M. Alencar. 2011. Composição fenólica e atividade antioxidante de resíduos agroindustriais. Ciência Rural 41:1088-1093.

Mulero, J., F. Pardo, P. Zafrilla, P. 2010. Antioxidant activity and phenolic composition of organic and conventional grapes and wines. Journal of Food Composition and Analysis 23:569-74.

Nozaki, V. T., C.L. Munhoz, R.C.A. Guimarães, P.A. Hiane, M.P. Andreu, L.H. Viana, and M.L.R. Macedo. 2012. Perfil lipídico da polpa e amêndoa da guarirova. Ciência Rural 42:1518-1523.

Özvural, E. B., and H. Vural. 2011. Grape seed flour is a viable ingredient to improve the nutritional profile and reduce lipid oxidation of frankfurters. Meat Science 88:179-183.
Pala, U. C., and K. Toklucu. 2012. Effects of UV-C Light Processing on Some Quality Characteristics of Grape Juices. Food Bioprocess Technology 6:719-725.

Perestrelo, R., Y. Lu, S.A.O. Santos, A.J.D. Silvestre, C.P. Neto, J.S. Câmara, and S.M. Rocha. 2012. Phenolic profile of Sercial and Tinta Negra $\mathrm{Vi}$ tis vinifera $\mathrm{L}$. grape skins by HPLC-DAD-ESI$\mathrm{M}^{\mathrm{Sn}}$ : Novel phenolic compounds in Vitis vinifera L. grape. Food Chemistry 135:94-104.

Rockenbach, I.I., G.L. Silva, E. Rodrigues, E.M. Kuskoski, and R. Fett. 2008. Influência do solvente no conteúdototal de polifenóis, antocianinas e atividade antioxidante deextratos de bagaço de uva (Vitis vinifera) variedades Tannat e Ancelota. Revista Ciência e Tecnologia de Alimentos 28:238-244.

Sáyago-Ayerdi, S. G., A. Brenes, and I. Goñi. 2009. Effect of grape antioxidant dietary fiber on the lipid oxidation of raw and cooked chicken hamburgers. Food Science and Technology 42:971-976.

Sousa Bentes, A., H.A.L. Souza, M.G. Simões, and X.M.F.D. Mendonça. 2009. Caracterização física e química e perfil lipídico de três espécies de peixes amazônicos. Revista Brasileira de Tecnologia Agroindustrial 03:97-108.

Souza, A. V., G.P.P. Lima, and R.L. Vieites. 2011. Avaliação nutricional de diferentes variedades de uva (Vitis sp). Naturalia 33:12-21.

Tagle, M. A. 1981. Nutrição. Editora Artes Médicas. São Paulo, Brasil. 233 pp.

Tseng, A., and Y. Zhao. 2013. Wine grape pomace as antioxidant dietary fibre for enhancing nutritional value and improving storability of yogurt and salad dressing. Food Chemistry 138:356-365.

Turan, H., G. Sönmez, and Y. Kaya. 2007. Fatty acid profile and proximate composition of the thornback ray (Raja clavata L. 1758) from the Sinop coast in the Black Sea. Journal fisheries Sciences 1:97-103. 